Bull. Fac . Agric., Cairo Univ., 65:455-463 (2014).

\title{
LIFE TABLE STUDY OF THE COTTON LEAFWORM, Spodoptera littoralis (Boisd.) (Lepidoptera: Noctuidae) ON FIVE HOST PLANTS
}

\author{
(Received : 23.11. 2014)
}

\author{
By \\ A.W. Makkar, H. M. H. Al-Shannaf, M. A. El-Hamaky and A. L. Sokkar \\ Plant Protection Research Institute, Agricultural Research Center, Dokki, Giza, Egypt.
}

\begin{abstract}
The cotton leafworm, Spodoptera littoralis (Boisd.) is an important pest on cotton and feeds on other host plants. In this study, development rate, age-specific survival and age-specific fecundity of cotton leafworm larvae reared on five host plants, (cotton, tomato, cabbage, zorbeyhh and mulberry) under laboratory conditions were studied for two successive generations. Results revealed that the cotton leafworm larvae survived on four host plants, but young larvae failed to survive on the fifth host (Mulberry). Thus, in both generations, the four host plants could be arranged according to their suitability for insect development in the following descending order cotton, tomato, cabbage and zorbeyhh. The least percentages of natural mortality were 9.02, 8.0, 7.44 and $1.02 \%$ when larvae were fed on cotton leaves for AM, RM, IM and MSR\% mortality, respectively. Meanwhile, the highest mortality rates were $77.46,32.30,25.84$ and $18.56 \%$ for AM, RM, IM and MSR\% mortality, respectively, when larvae were fed on zorbeyhh leaves. At the same time, cotton leaves harbored the highest net reproductive rate (Ro) 593.38 females/female, while, the shortest reproductive rate was 21.8 females/female obtained when larvae were fed on zorbeyhh leaves. Also, the longest mean generation duration (Gt) was 39.99 days when larvae were fed on zorbeyhh leaves, while, the moderate duration was 32.10 days on cotton. The population intrinsic rate $(\mathrm{rm})$ decreases from $0.1989,0.1336,0.1174$ to 0.0783 individuals/female/day and the finites rate of increase $(\lambda)$ were $1.220,1.135,1.25$, and 1.085 individuals /female/ day on cotton, tomato leaves, cabbage leaves and zorbeyehh leaves, respectively. The highest intrinsic and finite rates of increase of $S$. littoralis were obtained when larvae were fed on cotton leaves. The population of cotton leafworm moth doubled once every $4.37,6.87,8.04$ and 11.62 days when larvae were fed on the leaves of cotton, tomato, cabbage and zorbeyehh, respectively.
\end{abstract}

Key words: cotton leafworm (Spodoptera littoralis (Boisd.)), host plants, life table.

\section{INTRODUCTION}

The cotton leafworm, Spodoptera littoralis (Boisd.) (Lepidoptera: Noctuidae) is one of the most destructive agricultural lepidopterous pests within its subtropical and tropical range. Also, it is a key pest for wide range of economical pests on cotton. The effect of larval diet on the biology of this pest was studied by many authors (Basu, 1943; Nasr and Ibrahim, 1965; Badr, 1967 and Patel et al., 1968). Also, Moussa, et al., (1960) mentioned that there is approximately 112 hosts of the cotton leafworm, in tropical and temperate zones of the old world. These plants include 73 species recorded in Egypt. Consequently, several authors namely (Badr, 1982; Rizk et al., 1988; Mohamed, 2003; and Adham, et al., 2009) contributed to the biology of $S$. littoralis and the effect of different host plants on its development and reproductive capacity. That may cause considerable damage by feeding on the leaves of field crops cotton and vegetables., fruiting points, flower buds and occasionally, also, on bolls (Salama et al., 1971). In vegetables $e$.g. tomatoes, larvae bore into fruit which is, thus, rendered unsuitable for consumption. Numerous other crops are attacked, mainly on their leaves (Salama et al., 1971). As in the other polyphagous moths, the availability of different host plants plays an important role in population increase and spread (Hunter and McNeil 1997). Different host plants are known to affect insect development, survival, reproduction and life table parameters. (Richard 1961; Varley and Gradwell 1970; Greenberg et al., 2001; Hansen et al., 2004 and Liu et al., 2004). 
However, there is no information about life table parameters for $S$. littoralis on all host plants. Thus, demographic data could help assess the potential of population increase on cotton plants as well as on other host plants found around cotton area. Furthermore, tables could help explain why $S$. littoralis outbreaks occur in cotton area in Egyptian Governorates. Therefore, the objective of this study was to determine the effect of five host plants such as tomato, zorbeyhh, cabbage, cotton and mulberry on the development, survival, reproduction and life table parameters (the net reproductive rate (Ro), generation time (days) Tc or Gt, intrinsic rate of increase $(\mathrm{rm})$, finite rate of increase $(\lambda)$ and population doubling time (Dt) on each host and mortality distribution of the cotton leafworm, $S$. littoralis in the laboratory.

\section{MATERIALS AND METHODS}

\subsection{Host plants}

Five host plants were used in this investigation namely:

1.Cotton, Gossypium barbadense L. Fam. Malvaceae.

2.Tomato Lycopersicum esculeatum Fam.

Solanaceae.

3.Cabbage, Brassica oleracea V. capitatu Fam. Cruciferae.

4.Zorbeyhh Chenopodium album Fam.

Chenopodiaceae.

5. Mulberry, Morus sp. Fam. Moraceae.

The five host plants belonging to five different families are reported as hosts of the cotton leafworm, S. littoralis.

The first three plants were cultivated in the field, but the other two hosts (zorbeyhh and mulberry) were collected from neighboring trees of mulberry and berseem field, to provide satisfactory amounts of fresh leaves daily. Routine agricultural practices were followed for the cultivated three host plants and no insecticidal treatments were applied.

\subsection{Test insect}

Cotton leafworm larvae were obtained from batches of eggs collected from neighboring field. Larvae were reared for one generation on the same host plant on which the following generation was evaluated. Larvae from the next generation were used for tests. A mean rear temperature of $27 \pm 2{ }^{\circ} \mathrm{C}$ and average relative humidity of $65 \pm 5 \%$ were recorded during the course of the present study.

\subsection{Feeding tests}

Groups of one hundred newly hatched larvae were fed each on one of the five host plant leaves. Each group was replicated 10 times, i.e. a total of 1000 larvae per host were tested. The larvae were kept in glass jars $(250 \mathrm{cc})$ each covered with muslin. The number of larvae in each jar was reduced to 20 as larvae grew in size. Fresh host plant leaves were offered daily and larvae were checked every day to determine their duration and the mortality rates among the different instars in each case. The process was contained every day for each replicate until feeding ceased in pre-pupa. The resulting pupae were kept each in a separate vial till the moths emerged. Pairs of newly emerged adults were kept in glass jars and were offered sugar solution at the concentration of $10 \%$ as food. Each jar was supplied with a small branch of Nerium oleander to act as a suitable site for oviposition. The deposited egg masses were collected and the number of eggs laid per female was counted. The procedures were repeated for two successive generations.

Data analysis: data were subjected to statistical analysis using complete randomized design (Gomize and Gomize 1984) moreover significant differences between the average of treatment were calculated according to Duncan (1955).

\subsection{Functions life table parameters}

Tables for age-specific survival (lx), and number of dying $(\mathrm{dx})$ during the age interval were established according to the method described by Birch (1948) and by Anderwartha and Birch (1954). In this method the life table parameters were constructed and including:

1- Insect's population density in the development stages.

2- Age specific and survival rated or life table function (Lx).

3- Age specific fecundity (Mx) within a generation.

The following equations were used to establish:

* Apparent mortality percentage :

$$
A M \%=\frac{d x_{1}}{l x_{1}} x 100, \frac{d x_{2}}{l x_{1}} x 100 \ldots \ldots
$$

* Real mortality :

$$
R M \%=\frac{d x_{1}}{l x_{1}} \times 100, \frac{d x_{2}}{l x_{2}} \times 100 \ldots . .
$$

Also, these values were estimated:

- Indispensable mortality (IM \%)

- Mortality - survivor ratio (MSR \%) was estimated. 


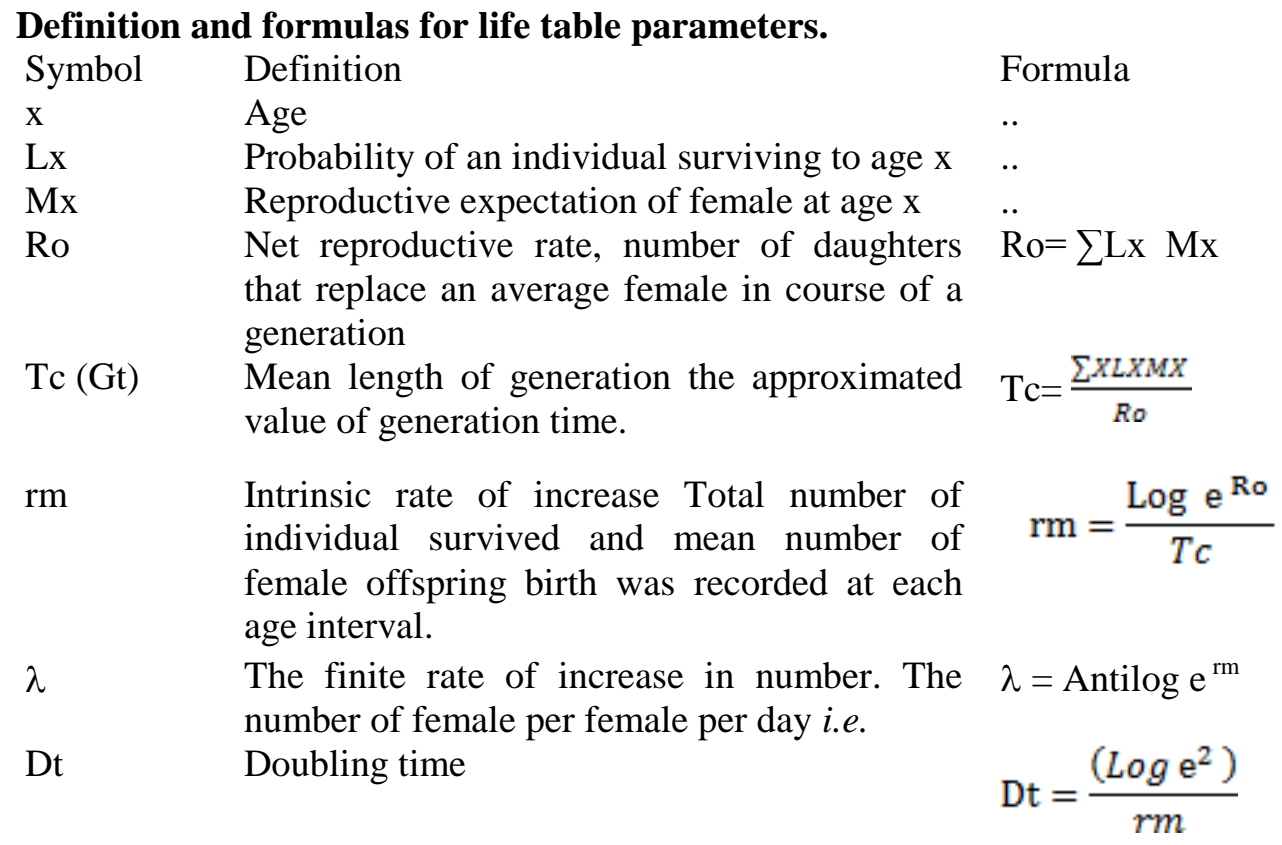

\section{RESULTS AND DISCUSSION \\ 3.1. Biological aspects}

Data in Table (1) show that the shortest mean incubation periods recorded for eggs of both generations were $3.5 \pm 0.12,3.4 \pm 0.09$ days on cotton, respectively. However, the highest means were $(5.8 \pm 0.05,5.85 \pm 0.12)$ and $(5.28 \pm 0.19$, $5.4 \pm 0.15)$ days on zorbeyhh and cabbage, in both seasons respectively.

The duration of larval stages of the cotton leafworm, S. littoralis was greatly affected by the different host plants. When larvae fed on zorbeyhh and cabbage leaves the highest larval mean durations were recorded $(20.91 \pm 0.08$, $20.73 \pm 0.15$ days respectively). Moderate durations were recorded on the other host plants, e.g. Tomato (17.3 \pm 0.12 days), cotton (17.56 \pm 0.16 days) in the $1^{s t}$ generation. The same trend was observed in the $2^{\text {nd }}$ generation. Moussa et al. (1960) and El.Saadany et al.(1994) reported that some hosts such as cotton tended to moderate duration of the larval stage.

Data also, show the effect of larval diet on the duration of the pupal stage, when larvae fed on tomato and cabbage leaves giving the highest pupal mean durations $(10.86 \pm 0.08,9.39 \pm 0.15$ days, respectively). Moderate durations were recorded on cotton and zorbeyhh $(7.87 \pm 0.07$, $8.08 \pm 0.08$ days, respectively) in the $1^{\text {st }}$ generation. The same trend was recorded in the $2^{\text {nd }}$ generation. Badr (1967) stated that the larval diet had some influence on the pupal period.
Also, the mentioned findings are in agreement with those cited by Salama et al. (1971), Nasr et al. (1973) and El-Saadany et al. (1994).

Data in Table (2), also indicated that larvae fed on cotton leaves gave the highest percentage of pupation (92.5\% \& 95\%) among the two generations, respectively. The contrary was obtained when larvae were fed on zorbeyhh $(22.5 \%$ \& $27.5 \%)$ respectively.

Also, the present data indicated that larvae fed on tomato and cotton leaves gave the highest percentages of adult emergence, while, when larvae were fed on zorbeyhh leaves they gave the shortest percentage of adult emergence in both generations.

In both generations, the sex ratio did not differ from 1:1 ratio. Data also, showed that larvae fed on cotton leaves gave the highest fecundity and egg hatchability. The contrary was obtained with zorbeyhh and cabbage.

Thus, cotton leaves proved to be the most suitable host plant for larval growth and development. On the other hand, zorbeyhh was the least suitable for S. littoralis. Also, in this study, cotton leaves proved to be the most favorable host plant for egg production. Moths originating from larvae fed on this host plant laid the highest number of eggs $(1610.8 \pm 45.5)$ and $(1590.1 \pm 50.5)$ in both generations, respectively. However the results obtained by Badr (1967) revealed that females fed as larvae on tomato produced the highest number of eggs. 
Table (1): Biological effects of different host plants on the cotton leafworm, S.littoralis for two generations, under laboratory conditions.

\begin{tabular}{|c|c|c|c|c|c|c|c|c|c|}
\hline \multirow[t]{2}{*}{ Stages } & \multicolumn{4}{|c|}{$\begin{array}{c}\text { Host plants } 1^{\text {st }} \text { generation } \\
\text { Mean duration } \pm \mathrm{SE}\end{array}$} & \multicolumn{4}{|c|}{$\begin{array}{c}\text { Host plants } 2^{\text {nd }} \text { generation } \\
\text { Mean duration } \pm \mathrm{SE}\end{array}$} & \multirow{2}{*}{$\begin{array}{c}\begin{array}{c}\text { In both } \\
\text { generations }\end{array} \\
\text { Mulberry } \\
\end{array}$} \\
\hline & Cotton & Tomato & Cabbage & Zorbeyhh & Cotton & Tomato & Cabbage & Zorbeyhh & \\
\hline $\begin{array}{l}\text { Incubation } \\
\text { Period }\end{array}$ & $\begin{array}{c}3.50 \pm \\
0.12 \mathrm{a}\end{array}$ & $\begin{array}{l}4.7 \pm \\
0.09 \mathrm{~b}\end{array}$ & $\begin{array}{l}5.28 \pm \\
0.19 \mathrm{c}\end{array}$ & $\begin{array}{l}5.8 \pm \\
0.05 \mathrm{~d}\end{array}$ & $\begin{array}{c}3.4 \pm \\
0.09 \mathrm{a}\end{array}$ & $\begin{array}{l}4.45 \pm \\
0.16 \mathrm{~b}\end{array}$ & $\begin{array}{l}5.4 \pm \\
0.15 \mathrm{c}\end{array}$ & $\begin{array}{l}5.85 \pm \\
0.12 \mathrm{~d}\end{array}$ & $\begin{array}{l}6.30 \pm \\
0.19\end{array}$ \\
\hline $\begin{array}{l}\text { larval } \\
\text { instars } \\
\mathbf{1}^{\text {st }} \text { instar }\end{array}$ & $\begin{array}{c}2.01 \pm \\
0.11 \mathrm{a}\end{array}$ & $\begin{array}{c}2.01 \pm \\
0.07 \mathrm{a}\end{array}$ & $\begin{array}{c}2.45 \pm \\
0.03 \mathrm{a}\end{array}$ & $\begin{array}{c}2.0 \pm \\
0.15 \mathrm{~b}\end{array}$ & $\begin{array}{c}2.3 \pm \\
0.17 \mathrm{a}\end{array}$ & $\begin{array}{l}2.01 \pm \\
0.11 \mathrm{a}\end{array}$ & $\begin{array}{c}2.37 \pm \\
0.16 \mathrm{~b}\end{array}$ & $\begin{array}{c}2.17 \pm \\
0.17 \mathrm{~b}\end{array}$ & $\begin{array}{l}1.5 \pm \\
0.15\end{array}$ \\
\hline $2^{\text {nd }}$ instar & $\begin{array}{l}2.10 \pm \\
0.13 \mathrm{a}\end{array}$ & $\begin{array}{l}2.17 \pm \\
0.05 \mathrm{a}\end{array}$ & $\begin{array}{l}2.45 \pm \\
0.02 \mathrm{~b}\end{array}$ & $\begin{array}{c}2.4 \pm \\
0.11 \mathrm{~b}\end{array}$ & $\begin{array}{l}2.17 \pm \\
0.12 \mathrm{a}\end{array}$ & $\begin{array}{l}2.21 \pm \\
0.16 \mathrm{a}\end{array}$ & $\begin{array}{l}2.43 \pm \\
0.09 \mathrm{~b}\end{array}$ & $\begin{array}{l}2.37 \pm \\
0.12 \mathrm{~b}\end{array}$ & \multirow{14}{*}{ 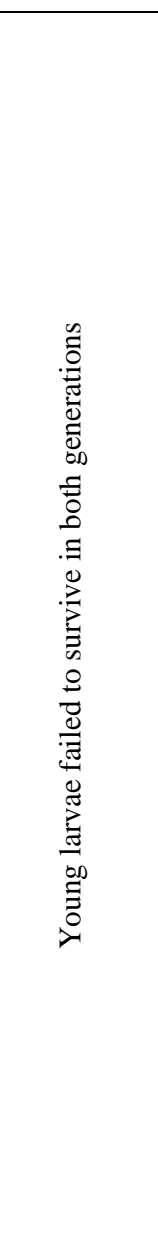 } \\
\hline $3^{\text {rd }}$ instar & $\begin{array}{l}2.37 \pm \\
0.11 \mathrm{a}\end{array}$ & $\begin{array}{l}2.27 \pm \\
0.06 \mathrm{a}\end{array}$ & $\begin{array}{l}2.96 \pm \\
0.02 \mathrm{~b}\end{array}$ & $\begin{array}{l}3.0 \pm \\
0.14 \mathrm{~b}\end{array}$ & $\begin{array}{l}2.33 \pm \\
0.17 \mathrm{a}\end{array}$ & $\begin{array}{l}2.37 \pm \\
0.25 \mathrm{a}\end{array}$ & $\begin{array}{l}2.92 \pm \\
0.16 \mathrm{~b}\end{array}$ & $\begin{array}{l}3.13 \pm \\
0.10 \mathrm{~b}\end{array}$ & \\
\hline $4^{\text {th }}$ instar & $\begin{array}{l}2.91 \pm \\
.013 \mathrm{~b}\end{array}$ & $\begin{array}{c}2.65 \pm \\
0.04 \mathrm{a}\end{array}$ & $\begin{array}{c}3.75 \pm \\
0.02 \mathrm{c}\end{array}$ & $\begin{array}{l}3.87 \pm \\
0.25 \mathrm{c}\end{array}$ & $\begin{array}{c}2.97 \pm \\
0.29 \mathrm{a}\end{array}$ & $\begin{array}{c}2.76 \pm \\
0.17 \mathrm{a}\end{array}$ & $\begin{array}{c}3.67 \pm \\
0.24 \mathrm{~b}\end{array}$ & $\begin{array}{c}3.91 \pm \\
0.25 \mathrm{~b}\end{array}$ & \\
\hline $5^{\text {th }}$ instar & $\begin{array}{l}3.60 \pm \\
0.12 \mathrm{a}\end{array}$ & $\begin{array}{l}3.17 \pm \\
0.11 \mathrm{~b}\end{array}$ & $\begin{array}{l}4.35 \pm \\
0.03 \mathrm{c}\end{array}$ & $\begin{array}{l}4.46 \pm \\
0.13 \mathrm{c}\end{array}$ & $\begin{array}{l}3.67 \pm \\
.17 \mathrm{~b}\end{array}$ & $\begin{array}{l}3.21 \pm \\
0.19 \mathrm{a}\end{array}$ & $\begin{array}{l}4.33 \pm \\
0.12 \mathrm{c}\end{array}$ & $\begin{array}{l}4.57 \pm \\
0.21 \mathrm{~d}\end{array}$ & \\
\hline $6^{\text {th }}$ instar & $\begin{array}{l}3.57 \pm \\
0.16 \mathrm{a} \\
\end{array}$ & $\begin{array}{l}5.03 \pm \\
0.12 \mathrm{c}\end{array}$ & $\begin{array}{l}4.77 \pm \\
0.03 \mathrm{~b}\end{array}$ & $\begin{array}{l}5.18 \pm \\
0.21 \mathrm{c}\end{array}$ & $\begin{array}{l}4.32 \pm \\
0.16 \mathrm{a}\end{array}$ & \begin{tabular}{ll}
\multicolumn{2}{c}{$5.1 \pm$} \\
$0.15 \quad \mathrm{~b}$
\end{tabular} & $\begin{array}{l}5.56 \pm \\
0.14 \mathrm{c}\end{array}$ & $\begin{array}{l}5.46 \pm \\
0.22 \mathrm{c}\end{array}$ & \\
\hline $\begin{array}{l}\text { Larval } \\
\text { duration }\end{array}$ & $\begin{array}{l}17.56 \pm \\
0.16 b\end{array}$ & $\begin{array}{l}17.3 \pm \\
0.12 \mathrm{a}\end{array}$ & $\begin{array}{c}20.73 \pm \\
0.15 \mathrm{c}\end{array}$ & $\begin{array}{l}20.91 \pm \\
0.08 \mathrm{c}\end{array}$ & $\begin{array}{c}17.49 \pm \\
0.07 \mathrm{a}\end{array}$ & $\begin{array}{c}17.6 \pm \\
60.13 \mathrm{a}\end{array}$ & $\begin{array}{l}21.28 \pm \\
0.16 \mathrm{~b}\end{array}$ & $\begin{array}{l}21.61 \pm \\
0.11 \mathrm{c}\end{array}$ & \\
\hline $\begin{array}{l}\text { Pupal } \\
\text { duration }\end{array}$ & $\begin{array}{c}7.87 \pm \\
0.07 \mathrm{a}\end{array}$ & $\begin{array}{l}10.86 \pm \\
0.08 \mathrm{~d}\end{array}$ & $\begin{array}{l}9.39 \pm \\
0.15 \mathrm{c}\end{array}$ & $\begin{array}{c}8.08 \pm \\
0.08 \quad b\end{array}$ & $\begin{array}{l}7.64 \pm \\
0.16 \mathrm{a}\end{array}$ & $\begin{array}{c}10.79 \pm \\
0.07 \mathrm{~d}\end{array}$ & $\begin{array}{l}9.47 \pm \\
0.15 \mathrm{c}\end{array}$ & $\begin{array}{l}8.18 \pm \\
0.07 \mathrm{~b}\end{array}$ & \\
\hline Pupation \% & $\begin{array}{l}92.5 \pm \\
4.15 \mathrm{c}\end{array}$ & $\begin{array}{l}42.5 \pm \\
2.17 \mathrm{~b}\end{array}$ & $\begin{array}{l}40.0 \pm \\
3.54 \mathrm{~b}\end{array}$ & $\begin{array}{l}22.5 \pm \\
2.17 \mathrm{a}\end{array}$ & $\begin{array}{l}95.0 \pm \\
2.5 \mathrm{~d}\end{array}$ & $\begin{array}{l}47.5 \pm \\
0.17 \mathrm{c}\end{array}$ & $\begin{array}{l}35.0 \pm \\
2.5 \quad b\end{array}$ & $\begin{array}{l}27.5 \pm \\
4.15 \mathrm{a}\end{array}$ & \\
\hline $\begin{array}{l}\text { Adult } \\
\text { emergence } \\
\%\end{array}$ & $\begin{array}{l}97.5 \pm \\
2.17 \mathrm{c}\end{array}$ & $\begin{array}{l}100.0 \pm \\
0.0 \mathrm{c}\end{array}$ & $\begin{array}{c}88.75 \pm \\
5.7 \mathrm{~b}\end{array}$ & $\begin{array}{l}79.17 \pm \\
10.83 \mathrm{a}\end{array}$ & $\begin{array}{l}94.72 \pm \\
2.65 \mathrm{ab}\end{array}$ & $\begin{array}{l}88.75 \pm \\
5.7 \text { a }\end{array}$ & $\begin{array}{l}87.5 \pm \\
6.25 \mathrm{a}\end{array}$ & $\begin{array}{l}85.42 \pm \\
7.44 \mathrm{a}\end{array}$ & \\
\hline sex ratio & & & & & & & & & \\
\hline Male & $\begin{array}{c}38.11 \pm \\
0.02\end{array}$ & $\begin{array}{c}46.11 \pm \\
0.23\end{array}$ & $\begin{array}{c}42.44 \pm \\
0.38\end{array}$ & $\begin{array}{c}41.79 \pm \\
0.01\end{array}$ & $\begin{array}{c}37.68 \pm \\
0.1\end{array}$ & $\begin{array}{c}45.84 \pm \\
0.18\end{array}$ & $\begin{array}{c}44.58 \pm \\
0.5 \\
\end{array}$ & $\begin{array}{c}44.06 \pm \\
0.27\end{array}$ & \\
\hline Female & $\begin{array}{c}37.29 \pm \\
0.22\end{array}$ & $\begin{array}{c}45.26 \pm \\
0.28\end{array}$ & $\begin{array}{l}41.97 \pm \\
0.27\end{array}$ & $\begin{array}{c}43.23 \pm \\
0.13\end{array}$ & $\begin{array}{c}36.85 \pm \\
0.19\end{array}$ & $\begin{array}{c}45.29 \pm \\
0.12\end{array}$ & $\begin{array}{c}42.75 \pm \\
0.48\end{array}$ & $\begin{array}{c}43.09 \pm \\
0.3\end{array}$ & \\
\hline $\begin{array}{l}\text { No.of eggs } \\
\text { /female }\end{array}$ & $\begin{array}{c}1610.8 \pm \\
45.5 \mathrm{~d}\end{array}$ & $\begin{array}{c}1327.6 \pm \\
44.4 \mathrm{c}\end{array}$ & $\begin{array}{l}927.6 \pm \\
14.12 \mathrm{~b}\end{array}$ & $\begin{array}{l}733.3 \pm \\
26.3 a\end{array}$ & $\begin{array}{c}1590.1 \pm \\
50.5 \mathrm{~d}\end{array}$ & $\begin{array}{c}1272.0 \pm \\
38.0 \mathrm{c}\end{array}$ & $\begin{array}{c}915.2 \pm \\
15.1 \mathrm{~b}\end{array}$ & $\begin{array}{c}766.9 \pm \\
45.1 \mathrm{a}\end{array}$ & \\
\hline $\begin{array}{l}\text { Hatchability } \\
\%\end{array}$ & $\begin{array}{l}88.7 \pm \\
0.27 \mathrm{~d}\end{array}$ & $\begin{array}{l}63.1 \pm \\
0.07 \mathrm{c}\end{array}$ & $\begin{array}{l}40.1 \pm \\
.37 \mathrm{a}\end{array}$ & $\begin{array}{l}41.7 \pm \\
0.17 \mathrm{~b}\end{array}$ & $\begin{array}{l}89.2 \pm \\
0.16 \mathrm{~d}\end{array}$ & $\begin{array}{l}68.3 \pm \\
0.05 \mathrm{c}\end{array}$ & $\begin{array}{c}39.7 \pm \\
0.29 \mathrm{a}\end{array}$ & $\begin{array}{l}45.3 \pm \\
0.13 \text { b }\end{array}$ & \\
\hline
\end{tabular}

Means followed by the same letters (difference between hosts in each generation) are not significantly different.

Finally, in both generations, young larvae failed to survive when larvae were fed on mulberry leaves.

Types of natural mortality, namely apparent mortality (AM), real mortality (RM), indispensable mortality (IM), and mortality survivor ratio (MSR) factors were accordingly studied and the obtained results are presented in Tables (2. 3, 4, and 5).

\subsubsection{Apparent mortality (AM)}

At egg stage, the apparent mortality reached the maximum (59.9 and 58.3\%) on cabbage and zorbeyehh, respectively, and the minimum (11.3 $\%$ ) on cotton in the $1^{\text {st }}$ generation. The same trend was recorded in the $2^{\text {nd }}$ generation, where the maximum (AM) values were (60.3 and $54.7 \%$ ) in the case of cabbage and zorbeyhh, respectively, while the minimum (AM) value was $(10.8 \%)$ on cotton.

The larvae showed the maximal percentage of (AM) $(77.46 \%)$ on zorbeyhh, whereas, the minimum death $(9.02 \%)$ was recorded on cotton. Also, pupal stage showed the highest mortality $(20.28 \%)$ on zorbeyhh, while the minimum death $(6.94 \%)$ was recorded on cotton in the $1^{\text {st }}$ generation. The same trend was recorded for larval and pupal stages in the $2^{\text {nd }}$ generation. 
Table (2): The change in the number of survival and mortality types in each age class of $S$. littoralis, when larvae were fed on cotton leaves during the $1^{\text {st }}$ and $2^{\text {nd }}$ generations.

\begin{tabular}{|l|c|c|c|c|}
\hline \multirow{2}{*}{ Measured age class } & \multicolumn{4}{c|}{$\mathbf{1}^{\text {st }}$ generation } \\
\cline { 2 - 5 } & \multicolumn{4}{c|}{ Stages } \\
\cline { 2 - 5 } & Eggs & Larvae & Pupae & Adults \\
\hline 1x & 1000 & 887 & 807 & 751 \\
\hline Dx & 113 & 80 & 56 & \\
\hline Apparent mortality (AM \%) & 11.3 & 9.02 & 6.94 & \\
\hline Real mortality (RM \%) & 11.3 & 8.0 & 5.6 & \\
\hline Indispensable mortality (IM \%) & 9.57 & 7.44 & 5.6 & \\
\hline Ratio (MSR) \% & 1.13 & 1.02 & 0.86 & \\
\hline & \multicolumn{5}{|c|}{$\mathbf{2}^{\text {nd }}$ generation } \\
\hline 1x & 1000 & 892 & 803 & 755 \\
\hline dx & 108 & 89 & 48 & \\
\hline AM \% & 10.8 & 9.98 & 5.98 & \\
\hline RM \% & 10.8 & 8.9 & 4.8 & \\
\hline IM \% & 9.14 & 8.37 & 4.8 & \\
\hline MSR \% & 1.08 & 1.12 & 0.74 & \\
\hline
\end{tabular}

Table (3): The change in the number of survival and mortality types in each age class of $S$. littoralis, when larvae were fed on tomato leaves during the $1^{\text {st }}$ and $2^{\text {nd }}$ generations.

\begin{tabular}{|l|c|c|c|c|}
\hline \multirow{2}{*}{ Measured age class } & \multicolumn{5}{|c|}{$1^{\text {st }}$ generation } \\
\cline { 2 - 5 } & \multicolumn{4}{|c|}{ Stages } \\
\cline { 2 - 5 } & Eggs & Larvae & Pupae & Adults \\
\hline $1 \mathrm{x}$ & 1000 & 631 & 268 & 239 \\
\hline Dx & 369 & 363 & 29 & \\
\hline AM \% & 36.9 & 57.33 & 10.82 & \\
\hline RM \% & 36.9 & 36.3 & 2.9 & \\
\hline IM \% & 27.41 & 32.37 & 2.9 & \\
\hline MSR \% & 3.7 & 9.12 & 4.04 & \\
\hline & \multicolumn{5}{|c|}{$\mathbf{2}^{\text {nd }}$ generation } \\
\hline 1x & 1000 & 683 & 324 & \\
\hline Dx & 317 & 359 & 36 & \\
\hline AM \% & 31.7 & 52.56 & 11.11 & \\
\hline RM \% & 31.7 & 35.9 & 3.6 & \\
\hline IM \% & 17.92 & 31.91 & 3.6 & \\
\hline MSR \% & 3.17 & 7.7 & 3.43 & \\
\hline
\end{tabular}

\subsubsection{Real mortality (RM)}

For the larval stage, the maximum real mortality $(36.3 \%)$ was obtained on tomato, while the minimum $(8.0 \%)$ on cotton. However, for pupal stage the maximum real mortality $(5.6 \%)$ was recorded on cotton, while, the minimum $(1.8 \%)$ on cabbage during the $1^{\text {st }}$ generation. The same trend was obtained for larval and pupal stages in the $2^{\text {nd }}$ generation.

\subsubsection{Indispensable mortality (IM)}

Indispensable mortality (IM) at egg stage was the maximum (9.57 and $9.14 \%$ ) on cotton in the two generations, respectively. On the other hand, indispensable mortality was high in the larval stage on all the tested host plants in both generations. Likewise, the IM for pupae was the maximum (5.6 and $4.8 \%$ ) on cotton, whereas, the minimum IM (1.8 and $1.7 \%)$ was recorded on cabbage in both generations, respectively.

\subsubsection{Mortality survivor Ratio (MSR)}

Mortality survival ratio, at egg stage was the maximum (6.0) on cabbage. At the larval stage, the maximum $(18.56 \%)$ was recorded on zorbeyhh. On the other hand, the minimum ratio of egg stage $(1.13 \%)$ was obtained on cotton. For larval stage, the minimum $(1.02 \%)$ was recorded on cotton. Furthermore, for pupal stages, the highest MSR (22.63\%) was observed on zorbeyhh, and the lowest $(0.86 \%)$ on cotton in the $1^{\text {st }}$ generation (Tables 2, 3, 4, and 5). 
Table (4): The change in the number of survival and mortality types in each age class of $S$. littoralis, when larvae were fed on cabbage leaves during the $1^{\text {st }}$ and $2^{\text {nd }}$ generations.

\begin{tabular}{|l|c|c|c|c|}
\hline \multirow{2}{*}{ Measured age class } & \multicolumn{4}{|c|}{$\mathbf{1}^{\text {st }}$ generation } \\
\cline { 2 - 5 } & \multicolumn{4}{|c|}{ Stages } \\
\cline { 2 - 5 } & Eggs & Larvae & Pupae & Adults \\
\hline 1x & 1000 & 401 & 160 & 142 \\
\hline Dx & 599 & 241 & 18 & \\
\hline AM \% & 59.9 & 60.1 & 11.25 & \\
\hline RM \% & 59.9 & 24.1 & 1.8 & \\
\hline IM \% & 39.14 & 21.39 & 1.8 & \\
\hline MSR \% & 6.0 & 15.0 & 7.0 & \\
\hline & \multicolumn{5}{|c|}{$\mathbf{2}^{\text {nd }}$ generation } & \\
\hline 1x & 1000 & 397 & 139 & 122 \\
\hline dx & 603 & 258 & 17 & \\
\hline AM \% & 60.3 & 64.99 & 12.23 & \\
\hline RM \% & 60.3 & 25.8 & 1.7 & \\
\hline IM \% & 19.0 & 22.64 & 1.7 & \\
\hline MSR \% & 6.0 & 16.0 & 9.0 & \\
\hline
\end{tabular}

Table (5): The change in the number of survival and mortality types in each age class of $S$. littoralis, when larvae were fed on zorbeyhh leaves during the $1^{\text {st }}$ and $2^{\text {nd }}$ generations.

\begin{tabular}{|c|c|c|c|c|}
\hline \multirow{3}{*}{ Measured age class } & \multicolumn{4}{|c|}{$\mathbf{1}^{\text {st }}$ generation } \\
\hline & \multicolumn{4}{|c|}{ Stages } \\
\hline & Eggs & Larvae & Pupae & Adults \\
\hline $1 \mathrm{x}$ & 1000 & 417 & 94 & 74 \\
\hline Dx & 583 & 323 & 20 & \\
\hline AM \% & 58.3 & 77.46 & 20.28 & \\
\hline RM \% & 58.3 & 32.3 & 2.0 & \\
\hline IM \% & 10.57 & 25.84 & 2.0 & \\
\hline \multirow[t]{2}{*}{ MSR \% } & 5.83 & 18.56 & 22.63 & \\
\hline & \multicolumn{4}{|c|}{$2^{\text {nd }}$ generation } \\
\hline $1 \mathrm{x}$ & 1000 & 453 & 125 & 107 \\
\hline $\mathrm{dx}$ & 547 & 328 & 18 & \\
\hline AM \% & 54.7 & 72.41 & 14.4 & \\
\hline RM \% & 57.7 & 32.8 & 1.8 & \\
\hline IM \% & 12.92 & 28.1 & 1.8 & \\
\hline MSR \% & 5.47 & 15.98 & 11.52 & \\
\hline
\end{tabular}

The same trends were reported for egg and pupal stages in the $2^{\text {nd }}$ generation, while, for the larval stage, the maximum ratio (MSR) was found on cabbage. Generally, for egg, larval and pupal stages, the minimum ratio existed on cotton.

All the values obtained from the above four types of mortality, indicated that the larval stage in the laboratory suffered the greatest mortality. This high percentage of mortality may be due to the photochemical contents of the leaves of the host plants.

\subsection{Life table parameters}

Table (6) summarizes the life table of $S$. littoralis on the four host plants under laboratory conditions.

\subsubsection{Net reproductive rate (Ro)}

The net reproductive rate, varied among hosts in different ways in this study. The results indicated that cotton achieved the highest net reproductive rate (Ro), with means of 592.63 and 593.35, respectively, in the two generations.

Moderate, net reproductive rate (Ro) was recorded on tomato and cabbage with means of 
133.08 and 86.87, respectively, in the $1^{\text {st }}$ generation, and $107.36 \& 66.16$, respectively, in the $2^{\text {nd }}$ generation. Zorbeyhh showed the least (Ro) values $(21.8,24.29)$ in the two generations, respectively. The net reproductive rate (Ro) is an important indicator of population dynamic (Richard 1961; Varley and Gradwell 1970).

It is a statistic key that summarizes the physiological capability of an animal relative to its reproductive capacity. Comparison of net reproductive rate often provides considerable insight beyond that available from the independent analysis of individual life history parameters (Liu et al., 2004).

\subsubsection{Mean generation time (days) (Gt or $\mathrm{Tc}$ )}

As shown in Table (6), the average generation time $(\mathrm{Gt})$ was obviously the longest $39.38,38.03$ and 36.6 days, when larvae were fed on zorbeyhh, cabbage and tomato leaves, in the $1^{\text {st }}$ generation.

A moderate generation time of 31.21 days took place when $S$. littoralis larvae reared on cotton leaves in the $1^{\text {st }}$ generation. The same trend was observed in the $2^{\text {nd }}$ generation.

\subsubsection{Intrinsic rate of increase $(\mathbf{r m})$}

The data in Table (6) revealed the changes in the intrinsic rate of increase $(\mathrm{rm})$ of cotton leafworm moth reared on four host plants. It can be concluded, that the population intrinsic rates decreased (rm) from $0.1988,0.1336,0.1174$, to 0.0783 individuals / female / day when larvae were fed on cotton, tomato, cabbage and zorbeyhh leaves. In this study, the highest value of intrinsic rate of increase was 0.1988 and 0.1989 individuals / female / day obtained when the larvae were reared on cotton leaves, in the $1^{\text {st }}$ $\&$ the $2^{\text {nd }}$ generations.

\subsubsection{Finite rate of increase $(\lambda)$}

The finite rate of increase $(\lambda)$ of the different host plants (Table 6) were 1.219, 1.143, 1.125 and 1.081 individuals / female / day when larvae were fed on cotton, tomato, cabbage and zorbeyhh leaves, respectively, in the $1^{s t}$ generation. The highest finite rate of increase $(\lambda)$ of $S$. littoralis was obtained on cotton leaves, 1.219 individuals / female / day, and the lowest was 1.081 , individuals/ female / day on zorbeyhh leaves in the $1^{\text {st }}$ generation. The same trend was obtained in the $2^{\text {nd }}$ generation. El- Saadany et al., (1994). The results of this study agreed with concerning the net reproductive rate (Ro), mean generation time $(\mathrm{Gt})$, intrinsic rate $(\mathrm{rm})$ and finite rate $(\lambda)$ of cotton leafworm moth $S$. littoralis when larvae were fed on cotton leaves.

\subsubsection{Population doubling time (Dt)}

The population of cotton leafworm moth had to double once every $11.06,7.39,6.5$ and 4.37 days when the larvae reared on zorbeyhh, cabbage, tomato and cotton leaves, respectively, in the $1^{\text {st }}$ generation. Clearly, cotton leaves appear to be the most preferendum host plants for cotton leafworm moth when population doubling time was considered (Table 6). The same trend was obtained in the $2^{\text {nd }}$ generation. In general, the calculated biological parameters, Ro, Gt. rm, $\lambda$ and Dt indicated that cotton leaves were quite favorable for achieving the highest developmental and multiplication rates of $S$. littoralis, while, zorbeyhh, cabbage, and tomato leaves were the least. Thus, the results for the net

Table (6): Life table of S.littoralis fed on different host plants under laboratory conditions.

\begin{tabular}{|c|c|c|c|c|c|c|}
\hline $\begin{array}{l}\text { Host } \\
\text { Plants }\end{array}$ & 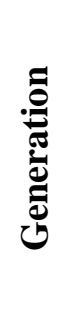 & 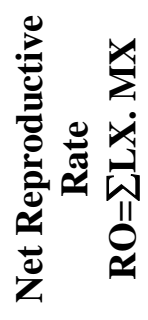 & : & 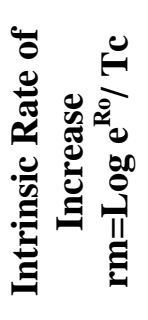 & 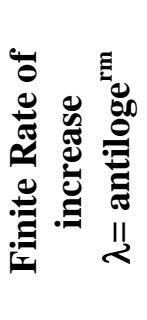 & 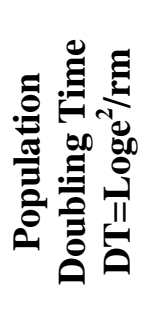 \\
\hline Cotton & $\begin{array}{l}1^{s t} \\
2^{\text {nd }}\end{array}$ & $\begin{array}{l}592.63 \\
593.35\end{array}$ & $\begin{array}{l}32.12 \\
32.10\end{array}$ & $\begin{array}{l}0.1988 \\
0.1989\end{array}$ & $\begin{array}{l}1.219 \\
1.220\end{array}$ & $\begin{array}{l}4.37 \\
4.37\end{array}$ \\
\hline Tomato & $\begin{array}{l}1^{s t} \\
2^{\text {nd }}\end{array}$ & $\begin{array}{l}133.08 \\
107.36\end{array}$ & $\begin{array}{l}36.6 \\
37.0\end{array}$ & $\begin{array}{l}0.1336 \\
0.1264\end{array}$ & $\begin{array}{c}1.143 \\
1.35\end{array}$ & $\begin{array}{l}6.50 \\
6.87\end{array}$ \\
\hline Cabbage & $\begin{array}{l}1^{s t} \\
2^{n d}\end{array}$ & $\begin{array}{l}86.87 \\
66.16\end{array}$ & $\begin{array}{c}38.03 \\
38.8 \\
\end{array}$ & $\begin{array}{l}0.1174 \\
0.1080\end{array}$ & $\begin{array}{l}1.125 \\
1.114\end{array}$ & $\begin{array}{l}7.39 \\
8.04\end{array}$ \\
\hline Zorbeyhh & $\begin{array}{l}1^{s t} \\
2^{n d}\end{array}$ & $\begin{array}{c}21.8 \\
24.29 \\
\end{array}$ & $\begin{array}{l}39.38 \\
38.99 \\
\end{array}$ & $\begin{array}{l}0.0783 \\
0.0818\end{array}$ & $\begin{array}{l}1.081 \\
1.085 \\
\end{array}$ & $\begin{array}{l}11.06 \\
10.62 \\
\end{array}$ \\
\hline
\end{tabular}


reproductive rate, the intrinsic rate of population increase indicated that cotton is more favorable than other host plants. Birch (1948) reported that, the intrinsic rate of population increase is a basic parameter which an ecologist may wish to establish for an insect population. Gotelli (1998) revealed that the value of rm determines whether a population increases exponentially $(\mathrm{rm}>0)$, remains constant in size $(\mathrm{rm}=0)$, or declines to extinction $(\mathrm{rm}<0)$. In this study, the intrinsic rate of population increase indicated that $S$. littoralis reared on four host plants exhibited exponential population growth. These findings are similar to those of Greenberg et al., (2001) and Hansen et al., (2004).

Finally, in the ecological study, life table is the most important analytical tool, which provides detailed information of population dynamics to generate simple but more informative statistics. Also it, gives a comprehensive description of the survivorship, development and expectation of life, (Ali and Rizvi 2007).

Intrinsic rate of increase and mean generation time reflect the suitability of the host plant. Where as survival and fecundity are affected by the host plant's nutritional value (Pereyra and Sanchez 2006).

This study provides a foundation regarding the host range of $S$. littoralis and it will be useful for pest management programs.

\section{REFERENCES}

Adham Fatma K., Rashad Eman M., Shouky C.F. and Nasr Enas E. (2009). Host plants shifting affects the biology, and biochemistry of Spodoptera littoralis (Boisd.) (Lepidoptera $=$ Noctuidae) J. Biolog. Sci. 2 (1): $63-71$.

Ali A. and Rizvi P.Q. (2007). Age specific survival and fecundity table of Coccinella septempunctata L., (Coleoptera = Coccinellidae) on different aphid species, Annals of plant protection sciences, 15: $329-334$.

Anderwartha H. G. and Birch L.C. (1954). The distribution and abundance of animals, Univ. of Chicago and London. p 298 308.

Badr N.A. (1967). Effect of different host plants on the development and reproduction of the cotton leafworm, Prodenia litura F. M. Sc. Thesis. Alexandria Univ., Egypt.

Badr N. A. (1982). Biological and ecological studies on the cotton leafworm,
Spodoptera littoralis (Boisd.) Ph. D Thesis Fac. Agric. Cairo Univ., Egypt.

Basu A.C. (1943). Effect of different foods on the larval and post larval development of the moth of Prodenia litura F. J. Bombay Nat. Hist. Soc. XLIV (2): 275 - 288.

Birch L.C. (1948). The intrinsic rate of increase of insect population, J. Anim. Ecol., 17:15-26.

Duncan D. B. (1955). Multiple range and multiple F. Test. Biometrics, 11: 1-42.

El-Saadany G.B., Hamed A.A., Zidan Aziza Z.H., Sharaby M. and Shadia Abdel Aziz. (1994). Biotic potential of the cotton leafworm, Spodoptera littoralis (Boisd.) (Lepidoptera: Noctuidae) on five host plants. $5^{\text {th }}$ conf. Agric. Dev. Res., Fac. Agric., Ain Shams Univ. Cairo, Egypt, 2: $927-944$.

Gomez K.A. and Gomez A.A.(1984). Statistical Procedures for Agricultural Research, $2^{\text {nd }}$ ed., John Wiley and Sons, New York, USA.

Gotelli N.I. (1998). A primer of ecology. Sinauer Associates. Inc. Sunderland, Massachusells, USA., 236 p.

Greenberg S.M., Sappington T.N., Legaspi B.C., Liu T.X. and Setamou M. (2001). Feeding and Life history of Spodoptera exigua (Lepidoptera : Noctuidae) on different host plants. Annals Entomol. Soci. Amer., Vol. 94 No (4): 566 - 575.

Hansen L.S., Skovgard H. and Hell L. (2004). Life table study of Sitotroga cerealella (Lepidoptera: Gelechiidae), a strain from west Africa. J. Econ. Entomol. 97 (4): $1484-1490$.

Hunter M.D. and McNeil J.N. (1997). Hostplant quality influences diapause and voltinism in a polyphagous insect herbivore. Ecol., 78 : 977 - 986.

Liu Z.D., Li D.M., Gong P.Y. I. and Wu L. (2004). Life table studies of the cotton bollworm, Helicoverpa armigera (Hubner) (Lepidoptera: Noctuidae), on different host plants. Environ. Entomol. 33 (6): 15701576.

Mohamed H. H. (2003). Comparative study of host plants on growth, development and fecundity of the cotton leafworm, Spodoptera littoralis (Boisd.) (Lepidoptera: Noctuidae) J. Egypt, Ger. Soc. Zool. 42E: $167-183$.

Moussa M. A., Zaher M.A. and Kotby F. (1960). 
Abundance of the cotton leafworm, Prodenia litura F. in relation on host plants. L. Host plants and their effect on biology. Bull. Soc. Ent. Egypt, 44: 241251.

Nasr El-Sayed A. and Ibrahim M. (1965). Contribution to the biology of the cotton leafworm, Prodenia litura F. with reference to larval colouration. Bull. Soc. Entom. Egypt, XLLX pp $159-162$.

Nasr E.S.A., El- Rafic K., Hosny M. M. and Badawi A. (1973). Effect of host plants on the biology of the cotton leafworm, Spodoptera littoralis (Boisd.) (Lepidoptera: Noctuidae). Bull. Soc. Ent. Egypt, 57: $27-32$.

Patel H. L., Patel R. M. and Patel V.C. (1968). Effect of food and temperature on the durations of various stages of tobacco leafeating caterpillar Prodenia litura F. India. Tob., Xv (4), $174-176$.

Pereyra P. C. and Sanchez N. E. (2006). Effects of two solanaceous plants on developmental and population parameters of the tomato leafminer, Tuta absoluta (Meyrick) $($ Lepidoptera $=$ Gelechiidae $)$. Neotropical Entomol. 35 (5): 671 - 676.

Richard O.W. (1961). The theoretical and practical study of natural insect populations. Anna. Rev. Entomol. 6: 147 162.

Rizk G.A., Hussein S.M. and Hafez H.F. (1988). Studies on biotic potential of the cotton leafworm, Spodoptera littoralis (Boisd.) with special reference to the effect of host plants on larval susceptibility to synthetic pyrethroids. Bull. Ent. Soc. Egypt, Econ. Ser., $17: 47-55$.

Salama E. S., Dimetry N. Z. and Salem S. A. (1971). On the host preference and biology of the cotton leafworm, Spodoptera littoralis (Boisd.). Z. Ang. Ent., 67: 261 266.

Varley G.C. and Gradwell G.R. (1970). Recent advances in insect population dynamics. Annu. Rev. Entomol. 15: 1- 24.

$$
\begin{aligned}
& \text { دراسة جدول الحياة لفراشة دودة ورق القطن المرباه على خمس عوائل نباتية } \\
& \text { عبدالمسيح وهبه مقار - حاتم محمد حاتم الثناف ـ محمد عبدالهادى الحماقى ـ عدلى لطيف سكر } \\
& \text { معهذ بحوث وقاية النباتات ـ مركز البحوث الزر اعية ـ الجيزة ـ مصر }
\end{aligned}
$$

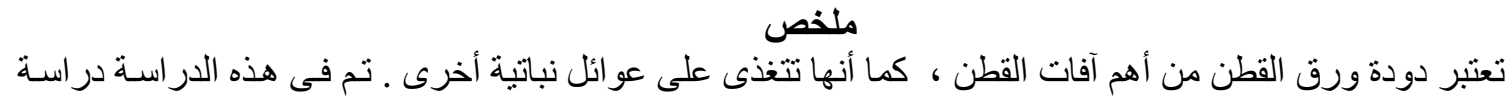

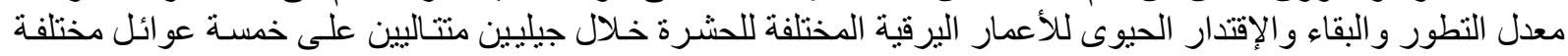

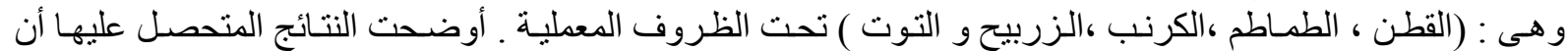

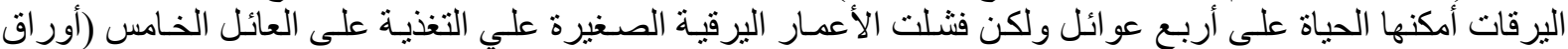

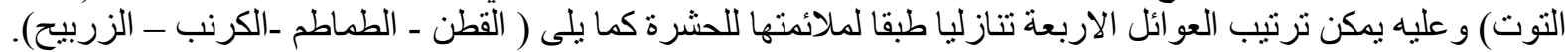

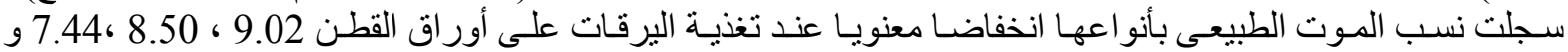

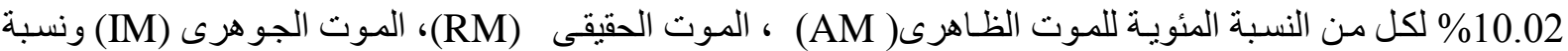

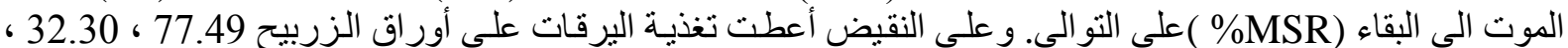

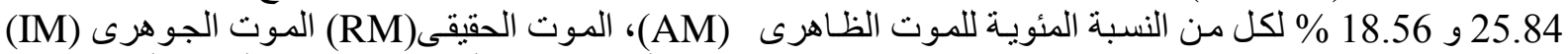

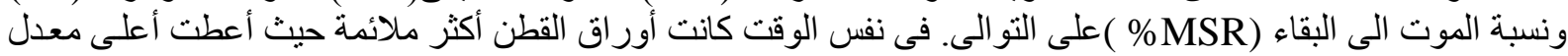

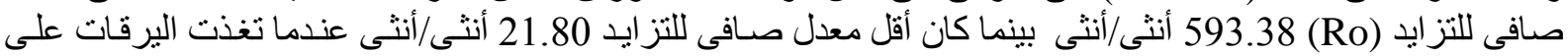

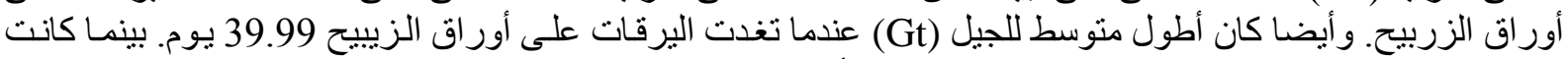

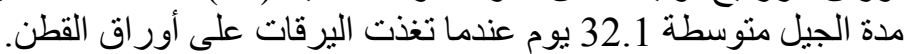

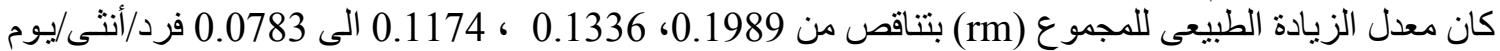

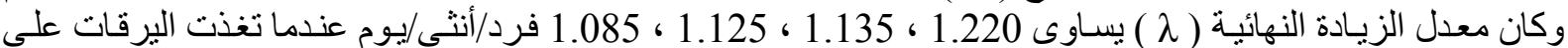

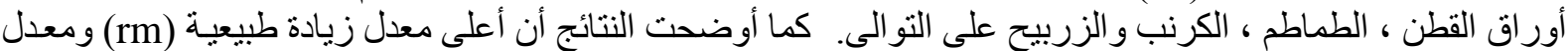

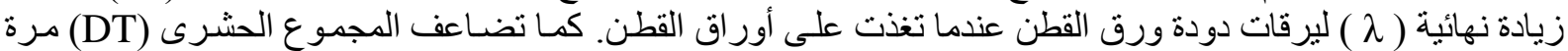

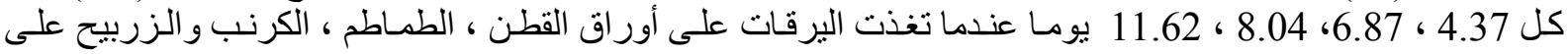

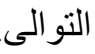

